\title{
Justice in Labor Immigration Policy
}

\author{
Caleb Yong
}

\begin{abstract}
I provide an alternative to the two prevailing accounts of justice in immigration policy, the free migration view and the state discretion view. Against the background of an internationalist conception of domestic and global justice that grounds special duties of justice between co-citizens in their shared participation in a distinctive scheme of social cooperation, I defend three principles of justice to guide labor immigration policy: the Difference Principle, the Duty of Beneficence, and the Duty of Assistance. I suggest how these principles are to be applied in both ideal and nonideal circumstances. Finally, I argue that the potential conflict between these principles has often been overstated, and propose priority rules for genuine cases of conflict.
\end{abstract}

Keywords: immigration; global justice; distributive justice; brain drain; international development

\section{Introduction}

In public debates on immigration policy, the admission of labor migrants - those who migrate in order to do paid work in the receiving stateattracts especially intense concern. ${ }^{1}$ Yet labor immigration has been relatively neglected by political philosophers. Some treatments of justice in immigration policy do not give labor migration attention as a distinct category. Others focus on whether expected economic contribution is legitimate as a general criterion for selecting among prospective immigrants. ${ }^{2}$ Among those accounts that examine substantive problems raised by labor immigration policy, most are focused on the "brain drain." 3 The

${ }^{1}$ Although labor migrants can be admitted on a temporary or more permanent basis, my discussion focuses primarily on long-term labor migration.

${ }^{2}$ See David Miller, National Responsibility and Global Justice (Oxford: Oxford University Press, 2007), pp. 222-23; Michael Blake, "Immigration and Political Equality," San Diego Law Review 45 (2008): 963-79, p. 972; Joseph H. Carens, The Ethics of Immigration (Oxford: Oxford University Press, 2013), pp. 183-85; and Peter W. Higgins, Immigration Justice (Edinburgh: Edinburgh University Press, 2013), pp. 202-22.

${ }^{3}$ See Fernando Tesón, "Brain Drain,” San Diego Law Review 45 (2008): 899-932; Gillian Brock, Global Justice: A Cosmopolitan Account (Oxford: Oxford University Press, 2009); Kieran Oberman, “Can Brain Drain Justify Immigration Restrictions?” Ethics 123 (2013): 427-55; Higgins, Immigration Justice, pp. 67-70, 213-22; and Douglas MacKay, “Are SkillSelective Immigration Policies Just?" Social Theory and Practice 42 (2016): 123-54. 
few comprehensive treatments of justice in labor immigration policy that examine both its domestic and international impact tend to reach the seemingly paradoxical conclusion that justice favors admission policies tilted toward and against high-skilled immigrants. ${ }^{4}$

This relative neglect of labor immigration can be explained by the tendency of views within the existing debate on justice in immigration policy to cluster around two positions: the free migration view and the state discretion view. According to the former, absent compelling countervailing considerations, justice requires states to admit all prospective immigrants. States lack even a qualified right to exclude migrants. According to the latter, the immediate family of citizens and refugees (including possibly "economic" refugees) aside, a receiving state rightly has broad discretion to choose which, if any, prospective immigrants to admit, constrained only by the imperative to avoid selecting immigrants according to certain objectionable selection criteria. Within a broad range, a receiving state has an unqualified right to admit or exclude prospective immigrants. ${ }^{5}$

Both of these views have sweeping implications for the assessment of labor immigration policies, which seem little able to capture the complexity of the moral issues at stake in specific policies. On the free migration view, all prospective migrants have a right to free migration; at the bar of ideal justice, any immigration policy short of open borders stands condemned. On the state discretion view, since restricting the admission of labor migrants falls within the range of receiving states' moral discretion, any labor immigration policy a receiving state might decide to pursue is just so long as it does not select among prospective migrants using criteria that are generally objectionable, such as criteria based on race or religious affiliation.

The tendency for existing treatments to be drawn to these polarized positions might seem puzzling if the debate is approached through what Simon Caney has called an isolationist methodology, where arguments about justice in immigration policy are constructed in isolation from general considerations of domestic and global justice. However, when viewed through an integrationist lens-where justice in immigration policy is

\footnotetext{
${ }^{4}$ See Lea Ypi, "Justice in Migration: A Closed Borders Utopia?" Journal of Political Philosophy 16 (2008): 391-418; and Stephen Macedo, "The Moral Dilemma of U.S. Immigration Policy: Open Borders Versus Social Justice?" in Carol M. Swain (ed.), Debating Immigration (Cambridge: Cambridge University Press, 2007), chap. 5, and "When and Why Should Liberal Democracies Restrict Immigration?" in Rogers M. Smith (ed.), Citizenship, Borders, and Human Needs (Philadelphia: University of Pennsylvania Press, 2011), chap. 14.

${ }^{5}$ For the distinction between qualified and unqualified rights to exclude, see Sarah Fine and Andrea Sangiovanni, "Immigration," in Darrel Moellendorf and Heather Widdows (eds.), The Routledge Handbook of Global Ethics (London: Routledge, 2015), chap. 16, p. 194.
} 
treated with explicit reference to a general background conception of domestic and global justice - it becomes easier to see why the free migration view and the state discretion view have been prominent: these views correspond to certain influential general conceptions of global justice. ${ }^{6}$

The free migration view is implied by globalism, which holds that fundamental principles of justice demanding equal protection for basic rights, equality of opportunity, and limits on inequalities in economic prospects apply to the global population as a whole. Any valid sub-global principles are constrained by, and subordinate to, these global principles. Each of these three fundamental commitments of globalism grounds an objection to immigration restrictions. First, taking freedom of movement to be a basic right, a global scheme of equal protection for basic rights requires protection for all persons' free movement across international borders. Second, immigration restrictions violate global equality of opportunity, since this minimally requires that jobs in any given state be formally open to foreigners. ${ }^{7}$ Third, since labor mobility tends to erode wage differentials not traceable to unequal labor productivity, immigration restrictions are objectionable because they entrench certain global economic inequalities that would not exist but for such restrictions. ${ }^{8}$

Hence, at least when bracketing problems of partial compliance, globalists should endorse the free migration view. It is therefore unsurprising that many prominent defenders of the free migration view, such as Joseph Carens, implicitly or explicitly adopt globalism as their background conception of global justice. ${ }^{9}$ Where globalism claims that principles requiring equal protection for basic rights, equal opportunities, and limits on economic inequality apply to the global population as a whole, internationalism holds that these principles apply specially among those who share membership in a state. According to internationalism, the principles of justice that apply among states, among humanity at large, and among persons joined in various cross-border relations each have a distinct content.

Since internationalists reject a global scheme of equal protection for basic rights, global equality of opportunity, and global economic egali-

${ }^{6}$ For the distinction between isolationist and integrationist approaches, see Simon Caney, "Just Emissions," Philosophy \& Public Affairs 40 (2012): 255-300, p. 259.

${ }^{7}$ Kok-Chor Tan argues that in an egalitarian global economic order, global equality of opportunity is compatible with restrictions on international migration. However, Tan seems to rely on an implausible interpretation of equality of opportunity that omits any requirement that jobs and other positions be open to free competition. See Kok-Chor Tan, Justice without Borders (Cambridge: Cambridge University Press, 2004), pp. 125-28.

${ }^{8}$ See Carens, The Ethics of Immigration, pp. 227-28; and Philippe van Parijs, "Marxism and Migration," in Marxism Recycled (Cambridge: Cambridge University Press, 1993), chap. 7.

${ }^{9}$ Carens, The Ethics of Immigration, chap. 11. 
tarianism, they are not bound by their background commitments to accept the free migration view. Indeed, many internationalists believe that the requirements of justice beyond borders are relatively minimal. Internationalists with such views will tend to believe that the constraints that justice places on the treatment of prospective immigrants-who are, of course, noncitizens - are also minimal. It is unsurprising, then, when theorists who adopt these minimalist internationalist conceptions endorse the rival state discretion view. ${ }^{10}$

Nevertheless, internationalists need not-and should not-be committed to the state discretion view. By largely deferring to the majority choices of a receiving state's citizenry regarding immigration policy, the state discretion view neglects the claims that different individuals and groups within that citizenry may have at the bar of domestic justiceclaims that may limit the range of permissible majority choice. In addition, the relatively meager constraints that the view imposes on receiving states' moral discretion are responsive only to the claims of two constituencies, namely, existing citizens and potential immigrants, ignoring the duties that might be owed to a third relevant constituency-those who remain behind in sending states.

In this article, I offer an alternative to the state discretion and free migration views. Adopting an integrationist method, I will take as my starting point one influential family of internationalist accounts of domestic and global justice, namely, conceptions that locate the special moral significance of state membership in co-citizens' common participation in a scheme of social cooperation. By reference to the background commitments of cooperation-based internationalism, I develop a comprehensive account of how labor immigration policy should be regulated by three principles of justice: the Difference Principle, the Duty of Beneficence, and the Duty of Assistance. ${ }^{11}$ I go on to address the worry that there are serious practical conflicts between the domestic and global demands of justice as they pertain to labor immigration policy, arguing that there is nothing paradoxical or incoherent about the three principles I defend.

\footnotetext{
${ }^{10}$ See Andrew Altman and Christopher Heath Wellman, A Liberal Theory of International Justice (Oxford: Oxford University Press, 2009); Michael Blake, "Immigration," in R.G. Frey and Christopher Heath Wellman (eds.), A Companion to Applied Ethics (Oxford: Blackwell, 2003), chap. 17; Blake, "Immigration and Political Equality"; Michael Blake, "Immigration, Jurisdiction, and Exclusion," Philosophy \& Public Affairs 41 (2013): 103-30; and Miller, National Responsibility.

${ }^{11}$ Note that my account of justice in immigration policy applies to policies regulating migrants' initial admission to legal residence, not to policies governing the acquisition of citizenship. For a discussion of labor immigration policy in connection with citizenship acquisition, see Ayelet Shachar and Ran Hirschl, "On Citizenship, States, and Markets," Journal of Political Philosophy 22 (2014): 231-57.
} 


\section{Cooperation-Based Internationalism and Justice in Immigration Policy}

Internationalist conceptions of global justice affirm two distinctive claims. First, they hold that co-membership in a state is a morally significant relation that grounds special principles of justice; these principles of domestic justice demand equal protection for basic rights, equality of opportunity, and limits on economic inequalities among co-citizens. ${ }^{12}$ Following Mathias Risse, I call this the view that the state is normatively peculiar from the standpoint of justice. ${ }^{13}$ Second, they hold that international and global principles of justice - which regulate the relations between states and between individuals joined in various forms of crossborder interaction, and which specify the duties we owe each other in virtue of our common humanity - make distinct demands. Different internationalist conceptions differ in terms of how they justify the normative peculiarity of the state, and how they specify the content of international and global principles of justice.

A rough taxonomy of the most influential internationalist conceptions within the global justice debate can be generated by differentiating three relations tracked by shared membership in a state that allegedly justify its normative peculiarity. According to nationalists, it is co-citizens' shared national identity that is significant. ${ }^{14}$ According to nonvoluntarists, it is instead co-citizens' shared subjection to a system of social rules, compliance with which is nonvoluntary. ${ }^{15}$ Cooperation-based internationalists propose a third account: it is co-citizens' shared participation in a system of social cooperation that justifies the special egalitarian principles of domestic justice. ${ }^{16}$

The integrationist strategy I pursue in this article will proceed against the background of cooperation-based internationalism, partly because some form of this view seems to me the most plausible conception of

\footnotetext{
${ }^{12}$ The "citizens" of a state should be understood to include all residents who stand in the social and political relation that makes the state normatively peculiar, even those who may not be legal citizens.

${ }^{13}$ Mathias Risse, On Global Justice (Princeton: Princeton University Press, 2012), p. 10.

${ }^{14}$ See Miller, National Responsibility.

${ }^{15}$ See Michael Blake, "Distributive Justice, State Coercion, and Autonomy," Philosophy \& Public Affairs 30 (2001): 257-96, and Justice and Foreign Policy (Oxford: Oxford University Press, 2013); Thomas Nagel, "The Problem of Global Justice," Philosophy \& Public Affairs 33 (2005): 113-47; and Risse, On Global Justice.

${ }^{16}$ See John Rawls, Political Liberalism (New York: Columbia University Press, 1996), and The Law of Peoples (Cambridge, Mass.: Harvard University Press, 1999); Andrea Sangiovanni, "Global Justice, Reciprocity, and the State," Philosophy \& Public Affairs 35 (2007): 3-39; and Risse, On Global Justice. Risse affirms a hybrid view that combines elements of nonvoluntarist and cooperation-based variants of internationalism.
} 
global justice, and partly because accounts of justice in immigration policy that assume globalism, or some nationalist or nonvoluntarist variant of internationalism, already have a strong presence in the philosophical literature. As I observed above, Carens's defense of the free migration view is rooted in his commitment to globalism. David Miller and Michael Walzer have each developed important defenses of the state discretion view that grow out of their background commitment to a nationalist conception of global justice. ${ }^{17}$ Michael Blake and Stephen Macedo each offer accounts of justice in immigration policy that assume some nonvoluntarist variant of internationalism. ${ }^{18}$ Only cooperation-based internationalism's implications for immigration policy have yet to be fully worked out ${ }^{19}$ this article aims to fill that lacuna.

Abstracting from the specific features of particular conceptions that various authors have proposed, I construct a generic cooperation-based internationalist view that will convey the distinctive claims of this type of internationalism while fixing some determinate principles that can then provide the framework for my subsequent discussion of justice in immigration policy. This constructed conception I name simply Generic Cooperation-Based Internationalism (GCBI). The remainder of this section will set out GCBI's account of the normative peculiarity of the state, its specification of the demands of justice beyond borders, and its general implications for justice in immigration policy.

According to GCBI, shared citizenship in a state is morally significant when that state's institutions furnish citizens with the resources they need to realize their moral powers: specifically, citizens' autonomy (i.e., the capacity to set and pursue life plans), and citizens' sense of justice (i.e., the capacity to participate in social and political life as moral agents). These resources, which following Rawls I call primary goods, include physical security, subsistence and basic healthcare, protection for basic civil and political rights, socially defined opportunities to develop and exercise various human faculties, and economic resources that facilitate the pursuit of a wide range of projects. ${ }^{20}$ The production of these primary

${ }^{17}$ See Miller, National Responsibility, chap. 8; and Michael Walzer, Spheres of Justice (New York: Basic Books, 1983), chap. 2.

${ }^{18}$ See Blake, "Immigration," and "Immigration and Political Equality"; and Macedo, "The Moral Dilemma of U.S. Immigration Policy," and "When and Why Should Liberal Democracies Restrict Immigration?"

${ }^{19}$ Ryan Pevnick's account of justice in immigration policy is arguably grounded in a form of cooperation-based internationalism. Nevertheless, it is unclear that Pevnick's argument pursues an integrationist rather than an isolationist strategy. Moreover, for Pevnick the significance of social cooperation is mediated through the idiosyncratic idea of cocitizens' associative ownership of their state's institutions. See Ryan Pevnick, Immigration and the Constraints of Justice (Cambridge: Cambridge University Press, 2011).

${ }^{20}$ See Rawls, Political Liberalism, pp. 180-81 and 187-90. 
goods requires appropriately structured social and political institutions, such as a system of criminal and constitutional law, a comprehensive education system, a system of healthcare and public health, the physical and legal infrastructure that enables complex economic activity in product and factor markets, and the mechanisms that organize the production of public goods and correct market failures.

Those states whose basic institutions are so structured that they enable the production and distribution of sufficient primary goods for all their citizens to realize, over their lifetimes, their moral powers to a fully adequate degree I will say have minimally just institutions. According to GCBI, in each state with minimally just institutions, it is the citizens of a given state - and not noncitizens - who collectively uphold and preserve that state's institutions through their lifelong compliance with institutional rules, their political engagement, and their contributions to tax revenues. In this way, those who share membership in a state with minimally just institutions are joint participants in a scheme of social cooperation whose cooperative product is the background framework that enables all participants to access the primary goods they need to realize their moral powers. ${ }^{21}$

As a participant in a particular scheme of cooperation, an individual acquires distinctive duties to other participants in that cooperative system - that is, to her co-citizens. The role of these duties of domestic justice is to secure a distribution of primary goods among citizens that satisfies an ideal of fair reciprocity among participants in a scheme of cooperation that furnishes each with the preconditions for the realization of her moral powers. Presumptively, only egalitarian distributions will satisfy this ideal: the maintenance of the institutions on which the production of primary goods depends is the collective achievement of all citizens, and no citizen can make a fairness-based claim to a greater share of the cooperative product than any other citizen. ${ }^{22}$

Departing from an equal distribution of the cooperative product is permissible, but only if all citizens have sufficient reason to accept the resulting inequalities. In a minimally just state, citizens will reasonably reject unequal protection for basic rights or inequality of opportunity. According to GCBI, therefore, justice among co-citizens demands equal protection for basic rights and equality of opportunity. But, following a familiar argument, GCBI recognizes that even those citizens with the worst economic prospects can accept the better prospects of other citizens if any reduction in economic inequalities would leave the former even worse off. GCBI therefore endorses Rawls's Difference Principle as a demand of

\footnotetext{
${ }^{21}$ See Sangiovanni, "Global Justice," pp. 19-21.

${ }^{22}$ See ibid., pp. 22-29; Risse, On Global Justice, p. 38; and John Rawls, Justice as Fairness: A Restatement (Cambridge, Mass.: Harvard University Press, 2001), p. 49 n.
} 
distributive justice among co-citizens; this principle licenses inequalities in economic prospects on the condition that these inequalities are generated by an overall cooperative scheme that works to the greatest benefit of the least advantaged citizens, compared to alternative schemes. ${ }^{23}$

With this account of domestic justice in hand, I now turn to GCBI's understanding of the principles of justice whose scope extends beyond state borders. This will be a partial account, focusing on only one potential ground of such duties: the moral concern that we owe each other simply in virtue of our common humanity. While GCBI recognizes that state-level cooperative schemes to maintain minimally just institutions are not the only morally significant forms of social cooperation, for present purposes I set aside other existing or incipient systems of international or global cooperation and the regulative principles that actually or potentially apply to them. I concede, of course, that these principles too may have implications for justice in labor immigration policy and to that extent my account is incomplete. ${ }^{24}$

To give content to the demands of justice that persons can make on each other qua human beings, I look to a pre-institutional duty that is implicit in GCBI's account of the normative peculiarity of the state. That account must explain why persons residing within the territory of a minimally just state are morally required to join that state's cooperative scheme-why, in other words, they may not withhold cooperation in order to evade the demands of fair reciprocity. This explanation will presumably invoke a pre-institutional duty to participate in social cooperation aiming at the maintenance of minimally just institutions where one lives.

This pre-institutional duty is in turn best justified, I argue, by appeal to two theses, one empirical and the other normative. The normative thesis claims that there is another, more fundamental, pre-institutional duty: to help - at a reasonable cost to the duty-bearer-all human persons access the resources they need to realize their moral powers to a fully adequate degree. I name this the Duty of Beneficence. The empirical thesis is familiar from GCBI's account of the normative peculiarity of the state. It asserts the instrumental necessity of minimally just institutions for the production of primary goods essential for individuals to realize their moral powers to a fully adequate degree.

As a duty that applies independently of duty-bearers' existing institutional ties, the scope of the Duty of Beneficence is universal: it is a principle of mutual aid among all human persons. According to the aforementioned empirical thesis, the Duty of Beneficence's goal can only be

\footnotetext{
${ }^{23}$ See Rawls, Justice as Fairness, pp. 122-24.

${ }^{24}$ Compare Adam Hosein, "Immigration and Freedom of Movement," Ethics \& Global Politics 6 (2013): 25-37, p. 35.
} 
fully achieved by ensuring that all human beings are governed by minimally just institutions. To this end, the Duty of Beneficence imposes four derivative duties. The first two apply where minimally just institutions already exist: (1) a duty to help maintain minimally just institutions within one's own state; and (2) a duty not to undermine minimally just institutions in other states. The second two apply in nonideal conditions, where minimally just institutions are absent: (3) a duty to help establish minimally just institutions in one's own society; and (4) a duty to help establish minimally just institutions in all societies where they do not currently exist. These nonideal duties, I will assume, do not demand more than can be done at a reasonable cost to the duty-bearers.

The fourth derivative duty I call, following Rawls and Risse, the Duty of Assistance. ${ }^{25}$ For reasons of their greater capacity, I take it that this duty falls especially on citizens of developed states, whose institutions are already minimally just. The Duty of Assistance requires that citizens of these states, when choosing which state policies to support politically, favor those policies - especially foreign, trade, development assistance, and immigration policies - that will promote the building of minimally just institutions in developing states, whose existing arrangements fail to provide their citizens with the resources they need to realize their moral powers to a fully adequate extent.

With this outline of GCBI in hand, I can now begin to consider its implications for justice in immigration policy. As an internationalist conception, GCBI rejects global distributive egalitarianism, and consequently denies that justice requires free migration in order to achieve socioeconomic equality globally. GCBI also rejects the argument that justice requires free migration because international freedom of movement is a basic right. According to GCBI, co-citizens are bound by special duties to protect each other's basic rights, including the right to freedom of movement. However, citizens of different states do not owe each other similar duties: justice does not mandate a globe-spanning scheme for the protection of basic rights. For this reason, while internal freedom of movement is a demand of (domestic) justice, international freedom of movement is not a demand of (global) justice.

The principles of GCBI, then, do not recognize free migration as a demand of justice - although of course they may require receiving states to authorize the admission of specific categories of prospective immigrants under certain conditions. This result only establishes, however, that immigration restrictions in general are not objectionable for the reason that they violate requirements of justice; they may still be objectionable for the more mundane reason that they forcibly interfere with the

\footnotetext{
${ }^{25}$ See Rawls, The Law of Peoples, pp. 105-12; and Risse, On Global Justice, pp. 80-81.
} 
agency of prospective immigrants without sufficient justification, violating a general moral duty not to limit individuals' negative liberty absent a sufficient justification. ${ }^{26}$ Advocates of this argument for free migration, such as Chandran Kukathas, frame their challenge in terms of a general presumption against restricting immigration, which familiar reasons for restriction allegedly fail to overcome. ${ }^{27}$

In assessing this challenge, a first step is to locate the justificatory standard set by the presumption in favor of prospective immigrants' negative liberty. Kukathas claims that the standard is especially stringent, since "we need ... very strong reasons to exercise force to prevent a person from acting." 28 To set up a stringent presumption against limiting negative liberty in this way, however, would be to assign it excessive deliberative weight relative to valuable social and political goals that could be served by imposing legal restrictions on individuals' conduct. As Ronald Dworkin has noted, because negative liberty is morally neutral in the sense that it encompasses the whole range of purposes to which a person's agency may be directed, regardless of their value or disvalue, there need be no "special justification - but only a justification" for restricting it. ${ }^{29}$

Thus, while I agree with Kukathas that there is a general presumption against limiting negative liberty, I submit that the justificatory standard this presumption sets is not especially strong, but requires only that the restrictions in question serve a sufficiently valuable cause. Hence I disagree that immigration restrictions can never, or only in exceptional cases, overcome it. Specifically, it is a sufficient justification for a particular set of immigration restrictions that: (1) they serve social and political goals that justice permits or indeed requires the receiving state to pursue; and (2) they do not violate specific duties to admit, or exclude, certain categories of prospective immigrants.

The role for principles of justice in immigration policy in this context is to clarify which goals receiving states are required or permitted to pursue through their immigration policies, and to specify when there are specific duties to admit or exclude certain categories of prospective immigrants. In the remainder of this article, I will formulate principles of justice for labor immigration policy specifically, informed by the background commitments of GCBI. In section 3, I examine what constraints principles of domestic distributive justice impose on labor immigration policy; in section

\footnotetext{
${ }^{26}$ For pressing me to address this point, I am grateful to an anonymous reviewer for Social Theory and Practice.

${ }^{27}$ See Chandran Kukathas, "Why Open Borders?" Ethical Perspectives 19 (2012): 649-75.

${ }^{28}$ Kukathas, "Why Open Borders?" p. 654.

${ }^{29}$ Ronald Dworkin, Taking Rights Seriously (Cambridge, Mass.: Harvard University Press, 1978), p. 269. See also Rawls, Justice as Fairness, pp. 44-45.
} 
4, I examine how global principles of justice should guide the choice of labor immigration policies. In section 5, I ask how the principles I defended in the previous two sections might fit together. Section 6 concludes.

\section{Domestic Distributive Justice and Labor Immigration Policy}

My discussion of how principles of domestic distributive justice might constrain labor immigration policy begins from within ideal theory: ${ }^{30}$ my general assumption will be that relevant agents are fully motivated to comply with what justice demands. More specifically, I assume that the world is populated only by developed states, and that each receiving state satisfies the migration-independent demands of domestic justice. At least when these assumptions of ideal theory hold, states are permitted to craft labor immigration policies guided by the aim of generating a higher level of primary goods - especially economic resources - than would be possible in a closed labor market.

This is a permissible aim of labor immigration policy because augmenting the production of primary goods is in general a permissible purpose for a state to pursue through its public policies. As we have seen, primary goods are instrumental to citizens' realization of their moral powers. In particular, greater access to economic resources generally facilitates the pursuit of various personal ends. Hence, by augmenting economic production, states promote their citizens' autonomy. Since the aim of promoting economic growth is continuous with what GCBI identifies as the basic purpose justifying state institutions, it is a generally permissible aim of public policy - including labor immigration policy. ${ }^{31}$

The pursuit of economic gains through labor immigration must, however, satisfy constraints imposed by relevant principles of domestic distributive justice. I contend that the relevant principle here is the Difference Principle. To see why, consider how labor immigration works to improve the economic prospects of a receiving state's citizens. First, migrant workers can alleviate labor shortages, increasing labor-market efficiency and easing growth bottlenecks. Second, migrant workers increase the productivity of native workers when there are complementarities between their skills and those of native workers. Finally, labor immigration increases productivity when migrants' skills complement the existing capital stock. ${ }^{32}$

${ }^{30} \mathrm{I}$ follow the distinction between ideal and nonideal theory found in John Rawls, $A$ Theory of Justice (Cambridge, Mass.: Harvard University Press, 1971), pp. 8-9 and 24546; and Rawls, The Law of Peoples, pp. 89-90.

${ }^{31}$ See MacKay, “Are Skill-Selective Immigration Policies Just?” p. 133.

${ }^{32}$ George Borjas, Heaven's Door (Princeton: Princeton University Press, 1999), pp. 88 and 99-102; Paul Collier, Exodus: Immigration and Multiculturalism in the 21st Cen- 
These mechanisms should not be evaluated simply at the level of discrete transactions between individual migrants and firms in the labor market, since such transactions are only possible against the background of a stable structure of complex economic institutions maintained by citizens' cooperative efforts. Labor immigration policy should therefore be conceived of as a form of economic restructuring: by opening its domestic labor market to migrant labor under specific conditions, a receiving state partially restructures its economy, thereby generating an economic surplus. According to GCBI, when evaluating a proposed restructuring of the economic system that they jointly maintain and participate in, citizens should be guided by the Difference Principle. It is this principle of domestic distributive justice, then, that provides the relevant standard in assessing specific labor immigration policies.

To recall, the Difference Principle licenses inequalities in different citizens' economic prospects only when these work to greatest benefit of the least advantaged. The justice of a given labor immigration policy, understood as a specific proposal for restructuring the economy, should therefore be tested by asking whether the inequalities in the restructured economy work to maximize the economic prospects of the least advantaged citizens compared to prevailing arrangements and other feasible restructured arrangements.

Crucially, when assessing labor immigration policy in light of the Difference Principle, the immediate labor market impact of the entry of migrant workers is not conclusive. For GCBI, market outcomes in themselves have no special moral significance, since market production is only one part of the whole cooperative system. Instead, it is the overall economic prospects of the least advantaged that are relevant. These prospects are to be measured in terms of the worst-off social class's lifetime economic expectations, inclusive of transfers and the provision of public goods, and taking into account the possibility of adjustments to initial market shocks.

To provide a concrete illustration of how the Difference Principle might guide the assessment of labor immigration policy, I consider a scenario in which prevailing labor immigration policies have led to lower wages and increased unemployment for low-skilled workers in receiving states, whom I will assume are among the least advantaged citizens of these states. Some economists believe that this been the actual labor market impact of recent immigration to developed states. For example, Christian Dustmann and his colleagues find that in the United Kingdom,

tury (London: Allen Lane, 2013), pp. 112-13; and Pia M. Orrenius and Madeline Zavodny, "Economic Effects of Migration: Receiving States," in Marc R. Rosenblum and Daniel J. Tichenor (eds.), The Oxford Handbook of the Politics of International Migration (Oxford: Oxford University Press, 2012), chap. 5. 
although most native workers experienced wage gains as a result of recent immigration, the wages of low-skilled workers declined. ${ }^{33}$ George Borjas reports that in the United States, immigration has similarly reduced the income shares of low-skilled native workers while raising those of high-skilled workers and owners of capital. ${ }^{34}$ Without taking a stand on the validity of these empirical claims, I ask what guidance the Difference Principle would offer in assessing the labor immigration policies of these states if their effects have indeed been to worsen the labor market situation of low-skilled workers.

According to a prominent account developed by Macedo, in such cases domestic distributive justice demands a shift toward more skill-selective immigration policies in order to shield low-skilled workers from the increased labor market competition that immigration brings. ${ }^{35}$ But as an application of the Difference Principle to labor immigration policy, Macedo's argument moves too quickly: in assessing a particular set of labor immigration policies, we must consider the effects of these policies, in conjunction with other economic policies and arrangements, on the lifetime economic expectations of the least advantaged citizens, not their immediate labor market impact.

Suppose that liberalizing restrictions on migrant labor will generate an overall economic surplus which is redistributed so as to boost the income expectations of the receiving state's least advantaged citizens. Suppose further that protective policies are implemented which successfully mitigate the adverse effects of immigration on the wage and employment situation of low-skilled workers. These policies might include strengthening labor unions, reinforcing unemployment insurance, providing macroeconomic stimulus, and expanding job retraining schemes, but also increasing labor market flexibility to facilitate job upgrading and the productive reallocation of any displaced workers. ${ }^{36}$ There may then be policy packages combining immigration liberalization with redistributive and protective policies that leave low-skilled workers with better economic prospects overall than Macedo's proposed skill-selective immigration policies.

The Difference Principle would favor such policy packages over Macedo's proposal. ${ }^{37}$ Even if the more restrictive immigration policies

${ }^{33}$ Christian Dustmann, Francesca Fabbri, and Ian Preston, "The Impact of Immigration on the British Labor Market," Economic Journal 115 (2005): F324-41.

${ }^{34}$ Borjas, Heaven's Door, pp. 103-4.

${ }^{35}$ Macedo, "The Moral Dilemma of U.S. Immigration Policy," p. 77, and "When and Why Should Liberal Democracies Restrict Immigration?" p. 320.

${ }^{36}$ On labor market flexibility, see Joshua D. Angrist and Adriana D. Kugler, "Protective or Counter-Productive? Labour Market Institutions and the Effect of Immigration on EU Natives,” Economic Journal 113 (2003): F302-31.

${ }^{37}$ For a similar argument, see Fine and Sangiovanni, "Immigration," pp. 206-9. 
are not best described as unjust, the Difference Principle would still judge them as suboptimal - merely what Rawls calls "just throughout"by comparison with policy packages that promise greater gains for the least advantaged. Indeed, the Difference Principle treats as the "best just" only those immigration policies that, when combined with redistribution and protection, raise the lifetime expectations of low-skilled workers to the point where further increases are no longer available. ${ }^{38}$

Macedo worries, however, that the redistributive and protective policies I have described are infeasible. ${ }^{39}$ In assessing this worry, it is crucial to distinguish between two ways in which policies might be infeasible. Policies are infeasible in the motivation-sensitive sense when their implementation is impeded by deficient moral motivation among relevant agents; policies are infeasible in the motivation-insensitive sense when their implementation is impeded due to causes for which no agent is morally responsible. In nonideal theory, the motivation-sensitive feasibility of proposed policies is appropriately taken into account, since the task of that branch of political theory is to propose responses to actual injustices in the status quo. ${ }^{40}$ By contrast, failures of moral motivation should be set aside in ideal theory, whose task is to determine what counts as justice and injustice in the first instance: here the relevant notion of feasibility is motivation-insensitive.

There is indeed some evidence that increased immigration reduces social expenditure and economic redistribution. ${ }^{41}$ However, the most influential hypotheses explaining the negative correlation between immigration rates and social expenditure seem to indicate a case of motivationsensitive infeasibility. For example, one proposed mechanism is that immigration has increased racial and ethnic diversity, and that unwillingness to support redistributive schemes that benefit ethnically different recipients has led to reduced support for spending on public goods and welfare programs. ${ }^{42}$ If true, this would show that the negative relationship between immigration rates and redistribution is due to some citizens' unjust motivations.

\footnotetext{
${ }^{38}$ See Rawls, A Theory of Justice, pp. 78-79, on the distinction between arrangements that are "best just" as opposed to merely "just throughout."

${ }^{39}$ Macedo, "The Moral Dilemma of U.S. Immigration Policy," pp. 79-80.

${ }^{40}$ Rawls, The Law of Peoples, p. 89.

${ }^{41}$ Stuart Soroka, Keith Banting, and Richard Johnston, "Immigration and Redistribution in a Global Era," in Pranab Bardhan, Samuel Bowles, and Michael Wallerstein (eds.), Globalization and Egalitarian Redistribution (New York and Princeton: Russell Sage Foundation and Princeton University Press, 2006), chap. 10.

${ }^{42}$ Alberto Alesina, Reza Baqir, and William Easterly, "Public Goods and Ethnic Divisions," Quarterly Journal of Economics 114 (1999): 1243-84; and Alberto Alesina and Edward L. Glaeser, Fighting Poverty in the US and Europe: A World of Difference (Oxford: Oxford University Press, 2004).
} 
A potentially more benign mechanism has been proposed by Robert Putnam, who argues that the increased ethnic diversity resulting from recent immigration has led to a general increase in social isolation. This in turn undermines the social trust that underpins support for redistribution and public expenditure. ${ }^{43}$ While this mechanism does not implicate "ethnically-defined group hostility," ${ }_{44}$ it does not indicate that the resistance to redistribution and social expenditure thaat accompanies immigration cannot be attributed to motivational deficits. Presumably, greater social isolation is not inevitably triggered by increased ethnic diversity. Rather, as Putnam himself insists, the effects of diversity on social trust are amenable to citizens' practical control - they can embrace a "more capacious sense of "we" that immunizes them from a "hunker down" reaction to greater diversity. ${ }^{45}$

Redistributive and protective policies are thus at least sometimes feasible policy options in the sense relevant for ideal theory. As such, even in cases in which liberalizing labor immigration will worsen the immediate labor market situation of the least advantaged citizens of the receiving state, the Difference Principle does not disfavor such liberalization provided that suitable redistributive and protective policies are implemented. To be sure, it may be that beyond certain levels of low-skilled immigration, redistributive and protective policies will cease to ensure that the overall prospects of the least advantaged citizens are enhanced or even protected. If low-skilled migrant workers and low-skilled native workers are to some extent substitutes in production, there may come a point where further increases in the supply of low-skilled migrant labor will predictably overwhelm efforts to boost wages and employment for low-skilled domestic labor or to redirect retrenched workers to other firms or sectors. Under these conditions, labor immigration would cause such significant unemployment among the least advantaged citizens that their overall economic prospects decline even with increased income transfers. Here redistributive and protective policies are infeasible in the motivation-insensitive sense, and satisfying the Difference Principle would require a more skill-selective immigration policy. ${ }^{46}$

\footnotetext{
${ }^{43}$ Robert D. Putnam, "E Pluribus Unum: Diversity and Community in the Twentyfirst Century," Scandinavian Political Studies 30 (2007): 137-74.

${ }^{44}$ Ibid., p. 150.

${ }^{45}$ Ibid., pp. 163-64.

${ }^{46}$ It may be objected that selecting among prospective immigrants on the basis of their job-relevant skills constitutes wrongful discrimination, since such skills are partially determined by innate talents, a characteristic for which individuals are not morally responsible. The permissibility of a selection criterion does not depend, however, on whether it tracks characteristics for which prospective immigrants are morally responsible, but whether it serves aims that a state is permitted to pursue through its public policies (see
} 
In nonideal theory, the relevant notion of feasibility shifts to the motivation-sensitive sense. If redistributive and protective policies are infeasible due to motivational failures, more skill-selective immigration policies might in some cases be the best option for a receiving state to protect the economic prospects of its least advantaged citizens. Nevertheless, even when trying to honor the Difference Principle under conditions of partial compliance, I suggest that restrictions on low-skilled immigration should not be given priority.

In choosing among reforms to combat some injustice, we should assess their comparative effectiveness - that is, the extent to which a given reform will successfully mitigate or eliminate the injustice in questionand prioritize more effective reforms. ${ }^{47}$ While the economic arrangements of actual states hardly work to the greatest benefit of their least advantaged citizens, there is evidence that liberalized labor immigration is a relatively unimportant cause of this distributive injustice. ${ }^{48}$ Assuming that this is the case, then even if relatively open labor immigration policies harm the economic prospects of the least advantaged citizens of receiving states, the desideratum of comparative effectiveness would caution against a focus on such policies rather than on other, more consequential, aspects of receiving states' economic arrangements. This consideration is especially salient given that, as will become clear in the next section, domestic distributive injustice in developed states is far from the only injustice that presently afflicts our world.

\section{Labor Immigration Policy and Duties to Noncitizens}

Having examined how domestic distributive justice constrains receiving states in pursuing the permissible aim of realizing economic benefits through labor immigration, I turn now to consider receiving states' duties to potential labor migrants and other noncitizens, again with GCBI as the background conception of global justice. The relevant principles for this discussion are the Duty of Beneficence and especially its derivative, the Duty of Assistance. Since in an ideal world populated solely by developed states, the Duty of Assistance and other nonideal aspects of the Duty of Beneficence are inert, my perspective will shift to nonideal theory. I

\footnotetext{
MacKay, "Are Skill-Selective Immigration Policies Just?" p. 131; and Blake, "Immigration and Political Equality," p. 972). Because when a receiving state uses skill-based selection to implement the Difference Principle, it is pursuing a permissible and indeed required aim, skill-based selection is not objectionable in this case. I thank an anonymous reviewer for Social Theory and Practice for pressing me to address this concern.

${ }^{47}$ Rawls, The Law of Peoples, p. 89.

${ }^{48}$ Dustmann et al., "The Impact of Immigration on the British Labor Market."
} 
ask now what constraints nonideal justice places on the labor immigration policy of a developed receiving state.

Currently, many states lack minimally just institutions and billions of persons lack any reasonable opportunity to realize their moral powers. Confronted with this unjust status quo, developed states are bound by justice to satisfy the Duty of Assistance and the Duty of Beneficence. More specifically, developed states are required to adopt policies that (1) assist persons who lack access to primary goods essential to realizing their moral powers to a fully adequate degree, especially by (2) promoting institutional reform in developing states, up to the point where doing more would impose unreasonable costs on them. ${ }^{49}$

In principle, the Duty of Beneficence and the Duty of Assistance specify only these overall aims and do not mandate that developed states adopt particular policies in pursuit of them. For a developed state to fully discharge these duties, the total effect of all its policies taken together must further the guiding aims specified by the duties, up to the reasonable cost threshold. Developed states are not required to ensure that any particular policy, among the many policy levers at their disposal across different policy domains, contributes positively toward achieving these aims. ${ }^{50}$ Hence, developed states in principle only have a reason - not a requirement-of justice to serve the Duty of Beneficence and the Duty of Assistance through their labor immigration policies specifically. Indeed, as Douglas MacKay has noted, a developed state may satisfy these duties even when it adopts labor immigration policies that set back the overall aims specified by the duties, provided that it also enacts policies in other domains, such as direct transfers of aid or reforms to the international trading regime, that sufficiently offset its labor immigration policies' harmful effects. ${ }^{51}$

Nevertheless, when there is serious uncertainty about the exact effects of particular policies, developed states will lack the information needed to reliably operationalize the "offsetting" strategies that MacKay suggests. In these cases, developed states are required to orient each relevant policy domain to the service of the Duty of Beneficence and the Duty of Assistance. Furthermore, under certain empirical conditions, implementing specific immigration policies is the only way to help build minimally just institutions in developing states, or to help severely deprived persons access essential primary goods, at reasonable cost. Here again, developed states are bound by a requirement of justice to implement the relevant immigration policies.

\footnotetext{
${ }^{49}$ Unfortunately, I cannot address here the difficult problem of precisely locating the reasonable cost threshold.

${ }^{50}$ MacKay, “Are Skill-Selective Immigration Policies Just?” p. 142.

${ }^{51}$ Ibid., pp. 143-44.
} 
In the rest of this section, I will examine more concretely some policies that developed receiving states might have reasons or requirements of justice to pursue in the service of the Duty of Beneficence and the Duty of Assistance. However, I do not necessarily endorse any specific proposals or the empirical claims on which the case for them depends; my primary purpose in considering specific reform proposals is to offer a detailed illustration of how my account can guide the assessment of particular policies.

I propose the following general deliberative framework: as we have seen, the Duty of Beneficence and the Duty of Assistance fix the overall goals of providing access to essential primary goods and promoting institutional reform, while specific proposed policies are to be assessed according to two desiderata for proposals in nonideal theory already encountered in section 3, namely, motivation-sensitive feasibility and effectiveness. ${ }^{52}$ Taking these desiderata to be scalar standards,${ }^{53}$ proposals are favored to the extent that (1) they are feasible in the motivation-sensitive sense; and (2) they are effective in mitigating or eliminating the injustices they target, by comparison with alternative policies.

I begin by considering how a developed state's labor immigration policies might serve the Duty of Assistance. The large-scale emigration of workers with advanced education or scarce skills from developing states potentially has very significant effects on the relevant sending states. This phenomenon is commonly labeled brain drain. While this term is sometimes used to denote any kind of skilled migration, including skilled migration between developed states, for present purposes it refers exclusively to the large-scale movement of workers from developing states to developed states.

Two ways in which brain drain can impede the establishment of minimally just institutions have been identified in the empirical literature. First, by depleting human capital, it can seriously destabilize certain forms of production that developing states must maintain if they are to furnish their citizens with primary goods essential for the realization of their moral powers. I call this the production destabilization mechanism. Second, skilled emigration can undermine long-term institutional reform by depriving developing states of a group of individuals who are disproportionately likely to be important catalysts for such reform. I call this the reform undermining mechanism.

Medical brain drain - the systematic emigration of medical workers from states with critically stressed basic healthcare systems-represents the most discussed case of the production destabilization mechanism, and

\footnotetext{
${ }^{52}$ See Rawls, The Law of Peoples, p. 89.

${ }^{53}$ See Holly Lawford-Smith, "Understanding Political Feasibility," Journal of Political Philosophy 21 (2013): 243-59.
} 
provides an especially clear illustration of this mechanism. Basic healthcare is an essential primary good whose provision requires an effective healthcare system. The density of resident medical workers relative to the general population is a significant determinant of the viability of an effective basic healthcare system. ${ }^{54}$ The unplanned large-scale emigration of health workers, when it sufficiently reduces medical worker density, destabilizes affected developing states' basic healthcare systems. ${ }^{55}$

When medical brain drain destabilizes or threatens to destabilize sending states' basic healthcare systems, developed states should curtail medical migration from affected sending states. This is a case where the Duty of Assistance imposes a requirement rather than simply a reason of justice, since the harms resulting from the absence of medical workers cannot be offset by transfers of aid alone: without adequate staffing levels, additional infusions of funding and medical supplies are likely to be wasted. ${ }^{56}$ Developed states have a duty to avoid actively recruiting doctors and nurses from any developing state unable to maintain basic healthcare provision due to staff shortages. They are also required to minimize medical immigration from affected states, for example, by cooperating with sending-state governments in enforcing a period of compulsory service for medical graduates before emigration is permitted, or by limiting employment visas for medical workers from affected states. ${ }^{57}$

Beyond imposing targeted immigration restrictions to minimize medical brain drain, developed states should also help address the institutional deficits that prompt high levels of medical emigration from developing states. For example, developed states can provide financial and technical assistance to improve the medical infrastructure and working conditions for medical workers in developing states. Since the Duty of Assistance is a general principle, not one restricted to immigration policy, immigration restrictions to combat medical brain drain should be seen as part of a broader set of policies to help establish viable basic healthcare systems in developing states.

The above account of how developed states' labor immigration policies should serve the Duty of Assistance in cases where brain drain causes production destabilization can be generalized from the specific example of medical brain drain. In other cases where skilled emigration critically impairs the production of essential primary goods in developing

${ }^{54}$ World Health Organization, World Health Report 2006: Working Together for Health (Geneva: WHO Press, 2006), p. 11.

${ }^{55}$ Peter Bundred and Cheryl Levitt, "Medical Migration," Lancet 256 (2000): 245-46.

${ }^{56}$ See Brock, Global Justice, pp. 199-200.

${ }^{57}$ On compulsory service programs, see Gillian Brock and Michael Blake, Debating Brain Drain: May Governments Restrict Emigration? (Oxford: Oxford University Press, 2015), pp. 73-79. 
states, and the harms cannot be reliably offset by financial transfers or other policy levers, developed states are required to adopt a similar policy mix: targeted restrictions on skilled immigration combined with wider efforts to help the affected developing states establish viable domestic structures to produce the relevant primary goods.

Consider next the reform undermining mechanism by which brain drain can impede the establishment of minimally just institutions in sending states. This mechanism focuses on skilled workers' role as potential institution builders and reformers, rather than their role in supplying critical human capital in production. According to Devesh Kapur and John McHale, skilled workers are typically better equipped than low-skilled workers to articulate and press demands for reform in the face of inertia or resistance from existing elites. Moreover, advanced education is associated with greater support for democratization and political reform. ${ }^{58}$ To the extent that skilled workers increase "both the supply of institution builders and the demand for better institutions," the brain drain tends to undermine institutional reform in developing states. ${ }^{59}$

Nevertheless, skilled emigration can also have effects that promote institutional reform in developing states. Three such effects have been identified: the diaspora effect, where an emigrant diaspora facilitates technical and commercial exchanges between sending and receiving states, and encourages foreign investment in sending states; the remittance effect, where remittances from skilled workers abroad support consumption and fund investment in sending states; and the return migration effect, where the return of skilled migrants who have enhanced their human capital abroad or who have acquired personal experience of liberal democratic institutions catalyzes economic and political development in sending states. ${ }^{60}$

If developed states choose to serve the Duty of Assistance through their labor immigration policies, they should adjust their policies according to the expected net effect of brain drain in various sending states. Determining these expected net effects in each case will require careful empirical analyses, and no definitive and comprehensive empirical guidance can be provided here. Again for illustrative purposes, however, I will consider some evidence regarding how a sending state's current level of development and its population size can affect skilled emigration's likely net impact on its political and economic development, and suggest

${ }^{58}$ Devesh Kapur and John McHale, Give Us Your Best and Brightest (Washington, D.C.: Center for Global Development, 2005), pp. 108-9. See also Brock and Blake, Debating Brain Drain, pp. 39-40.

${ }^{59}$ Kapur and McHale, Give Us Your Best and Brightest, pp. 5-6 and 97-98.

${ }^{60}$ Kapur and McHale, Give Us Your Best and Brightest; and Devesh Kapur and John McHale, "Economic Effects of Emigration on Sending Countries," in Rosenblum and Tichenor (eds.), The Oxford Handbook of the Politics of International Migration, chap. 6. 
how these empirical relationships might inform the crafting of a development-friendly labor immigration policy.

A sending state's existing level of development affects the likely impact that brain drain will have on domestic institutional reform: very poor states with the least developed institutions are more likely to suffer net setbacks to institutional reform, while developing states whose existing institutions are better functioning are more likely to experience a net boost to institutional development. ${ }^{61}$ Not only are skilled workers who face worse institutions more motivated to emigrate, but the worse a sending state's institutions are, the dimmer its prospects for attracting return migration. An emigrant is unlikely to return so long as the state she left is - and is likely to remain - afflicted by severely deficient institutions. ${ }^{62}$ As Kapur and McHale warn, the least developed states "can fall into a vicious cycle of bad institutions leading to emigration, leading to yet worse (or no better) institutions." 63

A sending state's population size affects the likely net impact of brain drain on domestic institutional reform: brain drain from smaller states is more likely to set back development overall than brain drain from larger states. ${ }^{64}$ States with smaller populations tend to experience a higher rate of skilled emigration, ${ }^{65}$ with the result that the negative effects connected with the absence of skilled workers tend to dominate any positive effects from diaspora connections, return migration, and the receipt of remittance income. Moreover, since many of the least developed states are small, the population-size and level-of-development factors often converge. ${ }^{66}$

If there is indeed a robust connection between the two factors outlined above and the predictable effects of brain drain on institutional reform in sending states, then developed states have a reason of justice to adopt labor immigration policies that differentiate between prospective skilled migrants from the least developed states with small populations and migrants from large developing states with better domestic institutions. Developed states should welcome skilled immigration from the latter group of sending states, such as China, India, and Brazil. In addition, receiving

\footnotetext{
${ }^{61}$ For a dissenting view, see Michel Beine, Frédéric Docquier, and Hillel Rapoport, "Brain Drain and Human Capital Formation in Developing Countries," The Economic Journal 118 (2008): 631-52.

${ }^{62}$ Collier, Exodus, pp. 201-2; and Alejandro Portes and Adrienne Celaya, "Modernization for Emigration," Daedalus 142, no. 3 (2013): 170-184, p. 180.

${ }^{63}$ Devesh Kapur and John McHale, "Should a Cosmopolitan Worry about the 'Brain Drain'?" Ethics \& International Affairs 20 (2006): 305-20, p. 313.

${ }^{64}$ Beine, Docquier, and Rapoport, "Brain Drain and Human Capital Formation."

${ }^{65}$ Frédéric Docquier and Abdeslam Marfouk, "International Migration by Education Attainment, 1990-2000," in Çaḡlar Özden and Maurice Schiff (eds.), International Migration, Remittances, \& the Brain Drain (London: Palgrave Macmillan, 2006), chap. 5.

${ }^{66}$ Collier, Exodus, p. 199.
} 
states should take steps to encourage the eventual return of some of these migrants, for example, by strengthening connections between the emigrant diaspora and the sending state. ${ }^{67}$ With respect to brain drain from small, severely underdeveloped states, such as those in sub-Saharan Africa and the Caribbean, by contrast, the Duty of Assistance gives developed states a reason of justice to minimize the immigration of skilled migrants.

By way of concluding my discussion of labor immigration policy and the Duty of Assistance, I address a familiar objection to the use of immigration restrictions to remedy the harms of brain drain. The general complaint of this Instrumentalization Objection is that counter-brain drain policies coerce some persons - namely, prospective skilled migrants - to labor for the benefit of others - namely, their co-citizens; for this reason, counter-brain drain policies fail to treat prospective migrants as "human beings who have their own goals and their own lives to lead." ${ }^{\prime \prime}$

An obvious initial response points out that counter-brain drain policies do not aim merely to confer a discretionary benefit on citizens of developing states, but to give them what they are due according to the Duty of Assistance. A reformulation of the Instrumentalization Objection might concede that counter-brain drain immigration restrictions are an effective way for developed states to serve the Duty of Assistance, but urge that there are other ways of satisfying that principle's requirements that would be less restrictive of prospective migrants' negative liberty.

Thus stated, the Instrumentalization Objection relies on an implicit principle that should be rejected or at least qualified: this principle holds that, for a coercive regulation to be permissible, even if that regulation serves goals that are morally required, it must leave the negative liberty of those it affects as uncircumscribed as possible. This principle is most plausible in cases in which the negative liberty at stake covers a domain of choice protected by a basic right. But a more general application of the principle would excessively prize mere negative liberty over other important values. Under a qualified rather than general application of the principle, however, the Instrumentalization Objection loses its force. According to GCBI, there is no basic right to freedom of international movement, and therefore the least restriction principle does not apply to counter-brain drain policies. ${ }^{69}$

Nevertheless, I agree that the imposition of counter-brain drain

\footnotetext{
${ }^{67}$ Kapur and McHale, Give Us Your Best and Brightest, pp. 181-88.

${ }^{68}$ Oberman, "Can Brain Drain Justify Immigration Restrictions?" p. 433. For a similar argument that appeals to full self-ownership, see Tesón, "Brain Drain."

${ }^{69} \mathrm{I}$ also assume that full self-ownership is not a basic right. For arguments in support of this assumption, see Nir Eyal and Samia A. Hurst, "Do Health Workers Have a Duty to Work in Underserved Areas?" in John D. Arras, Elizabeth Fenton, and Rebecca Kukla (eds.), The Routledge Companion to Bioethics (London: Routledge, 2014), chap. 9, pp. 126-27.
} 
measures should make room for an agent-centered prerogative that insulates these potential migrants from unreasonably burdensome personal costs: counter-brain drain policies fail to respect this prerogative if they deny entry to those skilled workers who would thereby suffer severe personal harms. Often, respecting skilled migrants' agent-centered prerogative will simply involve honoring their independent entitlements to admission. For example, if a skilled worker suffers persecution in her home state, she should not be denied asylum in a developed state, regardless of the effects on institutional reform or the provision of essential primary goods in her home state. Recognizing this agent-centered prerogative, however, does not ground a general objection to counter-brain drain immigration restrictions. Many skilled workers who work in developing states are able to lead lives good enough that counter-brain drain policies would not impose an unreasonable personal sacrifice on them. ${ }^{70}$

Having considered how the Duty of Assistance bears on labor immigration policy, I turn now to discuss the Duty of Beneficence more generally. While clearly the long-term goal of transforming the institutions of developing states is important, it is equally important for developed states to offer short-term remedies to individuals who are at present deprived of any reasonable opportunity to realize their moral powers. An exclusive focus on the Duty of Assistance and long-term reform would unduly neglect "those consigned to suffer injustice en route" during the long time period needed for institutional reforms to be realized. ${ }^{71}$

The Duty of Beneficence gives developed states a reason of justice to enact a policy of need-based immigration eligibility, under which any individual in the world whose current social environment denies her a reasonable opportunity to realize her moral powers would presumptively be given legal rights of entry to and settlement in a developed state. To assess the strength of this reason, we must look to the two desiderata for policies in nonideal theory, feasibility and effectiveness, and determine how well a need-based immigration eligibility scheme fares by these standards compared to alternative short-term remedies. In this context, a proposed short-term remedy is feasible to the extent that it is more likely to be adopted by the governments of developed states than alternative remedies, and it is effective to the extent that it will improve deprived

\footnotetext{
${ }^{70}$ See Nir Eyal and Samia A. Hurst, "Coercion in the Fight Against Medical Brain Drain," in Rebecca Shah (ed.), The International Migration of Health Workers: Ethics, Rights and Justice (London: Palgrave Macmillan, 2010), chap. 9, p. 150.

${ }^{71}$ Zofia Stemplowska and Adam Swift, "Rawls on Ideal and Nonideal Theory," in Jon Mandle and David A. Reidy (eds.), A Companion to Rawls (Oxford: Wiley-Blackwell, 2013), chap. 6, p. 120. See also David Miller, "A Tale of Two Cities; Or, Political Philosophy as Lamentation," in Justice for Earthlings (Cambridge: Cambridge University Press, 2013), chap. 10, p. 236.
} 
persons' access to essential primary goods to a greater degree than alternative remedies, for a given cost and within a given amount of time.

There is strong evidence that need-based immigration eligibility would be less feasible and less effective than alternative remedies in other policy domains. Granting immigration eligibility to anyone deprived of access to the resources she needs to realize her moral powers would massively expand immigration to developed states, especially low-skilled immigration. This result makes it very unlikely that need-based immigration eligibility will find political support; even relatively modest recent rates of immigration have stirred serious political opposition in most developed states. ${ }^{72}$ Such a policy is also relatively unlikely to be successful in improving access to essential primary goods at low cost. Given the scale of human deprivation in the world as we find it, significantly remedying global deprivation through migration would require immense population movements with very high transition costs.

By contrast, a policy of need-oriented international aid is likely to be more feasible and more effective. Transfers of aid would help the severely deprived in situ, for example, by strengthening existing programs that support consumption for those suffering severe poverty, and by helping to provide basic public services such as safe water, sanitation, basic healthcare, and education. This policy is more likely to gain acceptance politically, given that international aid enjoys relatively high public support in developed states. ${ }^{73}$ It is also likely more effective, since moving essential primary goods to deprived persons is generally less costly than having deprived persons move to and settle in a new society. ${ }^{74}$ This judgment of comparative effectiveness survives even granting the concerns of aid skeptics such as Angus Deaton and William Easterly. While they are dubious that external assistance can "transform governments or societies," they concede that interventions targeted at relieving specific and immediate needs have often been successful. ${ }^{75}$

\footnotetext{
${ }^{72}$ Recall that the relevant notion of feasibility here is motivation-sensitive. To the extent that need-based immigration schemes are effective but infeasible due to motivational deficits among the citizenry of developed receiving states, the immigration restrictions these states impose against needy prospective immigrants inflict seriously harmful coercion on the latter without sufficient justification. While agreeing with Michael Huemer that this is objectionable, in nonideal theory motivational limitations are regrettably relevant in deliberating about which reforms and policies to support, all things considered. See Michael Huemer, "Is There a Right to Immigrate?" Social Theory and Practice 36 (2010): 429-61.

${ }^{73}$ Lant Pritchett, Let Their People Come (Washington, D.C.: Center for Global Development, 2006), pp. 73-77 and 90-91. See also Thomas Pogge, "Migration and Poverty," in Veit Bader (ed.), Citizenship and Exclusion (Basingstoke: Macmillan, 1997), chap. 1.

${ }^{74}$ Pogge, "Migration and Poverty."

${ }^{75}$ William Easterly, The White Man's Burden: Why the West's Efforts to Aid the Rest Have Done So Much Ill and So Little Good (New York: Penguin, 2006), p. 368; Angus
} 
Nevertheless, a limited scheme that expands immigration - especially low-skilled immigration - from developing states can be seen as a policy that complements rather than competes with need-oriented international aid. Moreover, while schemes that produce general increases in permanent immigration by unskilled workers are likely to raise problems of infeasibility, a more tailored policy of need-based immigration might arouse less domestic political opposition.

Along these lines, Lant Pritchett has developed a plausible proposal for a quota scheme that expands temporary unskilled immigration but confines this expansion to specific labor market sectors that face demonstrable labor shortages. ${ }^{76}$ If political opposition to unskilled immigration stems from fear of detrimental labor market impacts and of rapid cultural change, then a scheme that limits eligibility for permanent settlement and channels migrants to only those market segments with clear shortages may help to allay these concerns. Favoring temporary over permanent migration would also increase the number of deprived persons who could benefit from this scheme.

\section{A Conflict of Principles?}

If the Difference Principle, the Duty of Beneficence generally, and the Duty of Assistance specifically all constrain labor immigration policy, how should receiving states adjudicate between these principles when their practical requirements come into conflict? One potential site of conflict is between honoring distributive justice among co-citizens of receiving states, on the one hand, and remedying injustices suffered by citizens of developing states, on the other. Other theorists of justice in immigration policy have alleged that this conflict is so serious that there may be a deep paradox of justice regarding immigration policy. Thus, Macedo claims that while "domestic distributive justice" favors skill-selective

Deaton, The Great Escape: Health, Wealth, and the Origins of Inequality (Princeton: Princeton University Press, 2013).

${ }^{76}$ Pritchett, Let Their People Come. Historically, temporary labor migration schemes have often left migrant workers vulnerable to exploitation by their employers, but a welldesigned scheme can guard against the risk of employer exploitation. For example, temporary migrants can be tied to a list of approved firms within a particular sector, rather than to specific employers. Pritchett's proposal to authorize firms in sending states as "labor mobility brokers" (p. 126), by introducing further checks and balances beyond the worker-employer relationship, would also reduce the risk of exploitation. For the contrasting view that any restriction on migrant workers' freedom of occupational choice amounts to exploitation, see Daniel Attas, "The Case of Guestworkers: Exploitation, Citizenship and Economic Rights," Res Publica 6 (2000): 73-92; and Joseph Carens. "Live-in Domestics, Seasonal Workers, and Others Hard to Locate on the Map of Democracy," Journal of Political Philosophy 16 (2008): 419-45. 
policies tilted toward admitting high-skilled labor migrants, "justice to poor sending countries" favors reducing skill selectivity in admissions. ${ }^{77}$ Similarly, Lea Ypi identifies a seeming "paradox of justice in migration": justice requires "both restricting the outflow of skilled migrants (from the perspective of emigration) and encouraging it (from the perspective of immigration)." 78

To ascertain whether there is a genuine conflict of principles here, a preliminary clarification is in order: is the question being raised within ideal or nonideal theory? There is not even the potential for conflict in ideal theory. On the assumption that the world is populated only by developed states, there would be no states lacking minimally just institutions and no individuals deprived of access to essential primary goods. Under these conditions, the nonideal aspects of the Duty of Beneficence, such as the Duty of Assistance, cease to apply. The potential for a conflict of principles therefore only arises in nonideal theory. Hence, there is no deep paradox that renders my integrationist account of justice in immigration policy incoherent: the need for compromises to be struck between the different requirements of justice it identifies only potentially arises in cases in which justice has already been compromised in some way.

Even in nonideal theory, the stark dilemma that Macedo and Ypi identify overstates the tension between domestic distributive justice and justice to noncitizens. In many cases, the practical requirements of the Duty of Beneficence and the Duty of Assistance do not come into conflict with those of the Difference Principle, simply because the former principles do not necessarily issue in requirements but only generate reasons of justice. There are presumably many measures that could be undertaken in policy domains other than immigration that would further the guiding aims of the Duty of Assistance and the Duty of Beneficencefrom enhancing development assistance to reforming those rules of the global economic order that incentivize poor governance and impede domestic institutional reform in developing states-without undermining the economic prospects of the least advantaged current citizens of developed receiving states. We have seen that when policies in these other domains score better in terms of feasibility and effectiveness, developed states have stronger reason to pursue them rather than pursue policies in the immigration domain. Avoiding clashes with the Difference Principle provides another reason to choose policies in other policy domains.

Macedo and Ypi also exaggerate the tension between domestic distributive justice and global justice because they mistakenly suggest that

\footnotetext{
${ }^{77}$ See Macedo, "When and Why Should Liberal Democracies Restrict Immigration?" p. 320; and Collier, Exodus, p. 261.

${ }^{78}$ Ypi, "Justice in Migration," pp. 412-15.
} 
the Duty of Assistance always favors reducing skill-selectivity in immigration admissions. Recall that skilled migration from larger, middleincome developing states may ultimately promote, rather than undermine, institutional reform in these sending states. At least with respect to these cases, there would be no clash between what the Duty of Assistance and the Difference Principle require. Finally, if the overall effect of labor immigration on the least advantaged citizens of receiving states is in fact negligible or even positive within a substantial range of immigration liberalization, then again the conflict between the Difference Principle and the short-term remedies called for by the Duty of Beneficence is more limited than Macedo and Ypi suggest. ${ }^{79}$

In cases where there is a genuine conflict between the practical requirements of the three principles of justice in labor immigration policy, there is a general priority rule for policies and reforms in nonideal theory that can guide receiving states in reaching a conclusive judgment about which policies to pursue overall. According to the comparative gravity principle, reforms that target graver or more severe injustices should be given priority over reforms that target less grievous injustices. This principle reflects the simple idea that the graver an injustice is, the stronger are the reasons for removing it. ${ }^{80}$ To be clear, this principle generates only pro tanto reasons; in evaluating competing reform proposals, the desiderata of motivationsensitive feasibility and effectiveness also have deliberative weight.

There are two ways to rank injustices according to their gravity: qualitatively and quantitatively. One injustice might be graver than another because the legitimate interests the former frustrates are qualitatively more urgent than those frustrated by the latter. Or one injustice might be graver than another because although the underlying interests are at the same level of urgency, the former simply affects more people than the latter. On both of these measures, the injustices suffered by deprived individuals in developing states are far graver than the injustices suffered by the least advantaged citizens of developed states. Qualitatively, while many citizens of developing states lack access to essential primary goods and are thereby denied the opportunity to even minimally realize their moral powers, the worst off in developed states are at least able to realize their moral powers to an adequate extent. Quantitatively, those affected by the lack of access to minimally just institutions and essential primary goods number in the billions, while the least advantaged

\footnotetext{
${ }^{79}$ See Gianmarco Ottaviano and Giovanni Peri, "Rethinking the Effect of Immigration on Wages," Journal of the European Economic Association 10 (2012): 152-97; and Gianmarco Ottaviano, Giovanni, Peri and Greg Wright, "Immigration, Offshoring, and American Jobs," American Economic Review 103 (2013): 1925-59.

${ }^{80}$ See Rawls, A Theory of Justice, p. 246.
} 
in developed states are comparatively fewer.

Considerations of comparative gravity would therefore favor prioritizing the requirements imposed by duties to citizens of developing states over the requirements imposed by fair reciprocity among citizens of developed states. To suggest this priority rule is not, of course, to deny the importance of correcting distributive injustice among co-citizens. The imperative of improving the economic prospects of the least advantaged in receiving states retains its deliberative significance, but is outweighed by competing moral goals.

\section{Conclusion}

The integrationist account of justice in labor immigration policy that I have defended provides a significant alternative to the prevailing state discretion and free migration views. Unlike the state discretion view, it denies that justice confers on receiving states almost unfettered discretion to pursue preferred collective goals through immigration policy; unlike the free migration view, it denies that receiving states are required to work toward the eventual implementation of open borders. Taking seriously the background commitments of GCBI, I have developed a rival deliberative framework to guide citizens of a developed receiving state in assessing and shaping their state's labor immigration policies: they should aim to progressively bring their state's labor immigration regime into conformity with the Difference Principle, the Duty of Beneficence, and the Duty of Assistance, evaluating proposed policies and reforms according to the two desiderata of motivation-sensitive feasibility and effectiveness, while prioritizing the remedy of different injustices according to their comparative gravity. ${ }^{81}$

\section{Edmond J. Safra Center for Ethics, Harvard University} cyong@ethics.harvard.edu

\footnotetext{
${ }^{81}$ For their helpful comments, I am grateful to Chris Armstrong, Paul Billingham, Jan Brezger, James Christensen, Andy Cohen, Luara Ferracioli, Adam Hosein, Jeff Howard, Andrew Lister, Matthew Lister, Catherine Lu, Kieran Oberman, Ayelet Shachar, Daniel Weinstock, and an anonymous reviewer for Social Theory and Practice. I am especially indebted to Arash Abizadeh, Jacob Levy, David Miller, and Annie Stilz for their extensive feedback. My thanks are also due to the Normative Theory of Immigration Working Group, and to audiences at the Graduate Political Theory Workshop and the Applied Ethics Discussion Group at the University of Oxford, the 2014 American Political Science Association Annual Meeting, the Research Group on Constitutional Studies Workshop at McGill University, and the Justice in Migration Workshop at the University of Amsterdam. I gratefully acknowledge the research support of the Research Group on Constitutional Studies, McGill University.
} 